\title{
アワビ類の育種の現状と将来
}

\author{
木島明博 \\ 東北大学大学院農学研究科 (複合生態フィールド教育研究センター)
}

\section{Current Studies on Genetics and Breeding Science in Abalone}

\author{
Akihiro KIJIMA \\ Integrated Field Science Center, Graduate School of Agricultural Science, Tohoku University
}

\section{1. はじめに}

アワビ類は東アジアにおいて古来より貴重な食料と されてきた。日本においてもその記録は奈良時代に遡 り、慰斗鮑 (のしあわび) などの縁起物や神事にも使わ れる高貴な生物である。また、万葉集にも登場し、有 名な「伊勢の海人朝な夕なに潜つぐ鮑の片想いにして」 でも知られ、江戸時代には俵物として中国に輸出され ていた歴史を持つ。現在でも日本人にとっては寿司ネ タとしてもなじみ深い水産動物である。

アワビ類とは軟体動物門・腹足綱・前鰓西綱・古腹 足目・ミミガイ科・ミミガイ属 (Haliotis) に属する巻 貝類の総称であり、世界で約 70 種、日本では 9 種 2 要 種が生息するとされている (日本近海産貝類図鑑)。こ のうち産業的に重要な種は暖流系アワビ類として大型 となるクロアワビ (Haliotis discus discus)、マダカアワ ビ (H. madaka)、メガイ (H. gigantea) と小型のトコブ シ (H. diversicolor aquatilis)、フクトコブシ $(H . d$. diversicolor)、そして日本では唯一の寒流系アワビ類 で大型となるエゾアワビ (H. discus. hannai) の 4 種と 2 亜種である。また、エゾアワビはクロアワビの寒冷地 方型とも考えられている。

それらの中でエゾアワビ (図 1、巻末のカラーページ 参照)は、その経済的価值が高いことや沿岸の比較的 浅い岩礁域に生息することから漁獲されやすく、近年 顕著な資源量の減少が認められている。そのため、日 本では天然に扔ける資源量の増加と安定漁獲を目的と して、人為的に親貝を成熟させ、人工的に種苗を生産 する技術の開発が 1960 年代から始められ、1980年代後 半にはその技術がほぼ完成された。その成果は浮ら （1995）によって詳細にまとめられている。また、その 技術は他種にも適用され、諸外国でも活用されている。

エゾアワビの生態学的、生理学的研究によって構築 された親貝の養成 (人為的催熟) 技術や人工種苗生産技
術は、沿岸域における資源量 (個体数)の増加ばかりで はなく、陸上養殖施設におけるエゾアワビの完全養殖 (生まれてから再生産までを人為管理下におく養殖)に も応用されるようになった。実際、中国では人工種苗 を放流することなく完全養殖による生産が急速にのび てきている。

全生涯を人為管理下に扔いて生産する完全養殖の場 合、自然界とは異なる環境において生産を上げなくて はならないことから、それに適した品種の作成が望ま れる。一方、天然への種苗放流は、無意識のうちに自 然集団 (自然遺伝資源) の遗伝的組成の変化を引き起こ す可能性があり、持続的生産のための集団の適正管理 方法の確立が望まれる。従って、エゾアワビの生産に はこれまでの生理学的、生態学的研究に加えて遺伝育 種学的研究が必要不可欠な段階になってきた。すなわ ち、遺伝的改良による新品種の作成 (閉鎖系) と、自然 における遺伝資源の改変をもたらさない(無意識選択 を生じさせない) 育種管理 (開放系)である。このよう な遺伝育種学的研究の 2 方向性は水産生物の大きな特 徵でもある(木島 1994)。

以上述べてきたことから、「アワビの育種」が遺伝 学を基盤とした生物の改良や系統の維持および自然遺 伝資源の保全と考えるならば、育種の対象となるのは 現在のところエゾアワビが中心になると考えられる。 本ミニレビューはエゾアワビの遺伝育種学的研究の現 状を紹介すると共に、これからのアワビの育種研究に

連絡先: 木島明博、東北大学大学院農学研究科沿岸生物生産シ ステム学 † 986-2242 宮城県牡鹿郡女川町小乗浜向 15 東北 大学大学院農学研究科附属複合生態フィールド教育研究センター (e-mail: a-kijima@mail.tains.tohoku.ac.jp) 
ついて概説する。

\section{2. エゾアワビの生物学的特徴と育種戦略}

育種とは、目標となる形質 (特徴)を持った生物ある いは生物集団を作成して維持するために、生物種が保 有する遺伝的能力を制御することであると考えられ る。また、育種技術とはその目標を達成するための遺 伝的制御技術であり、生物の持つ生物学的特徴によっ て様々な方策が考えられる。従って、ある生物の育種 を行う場合、対象生物の生物学的特徵を十分理解した 上で育種目標を揭げ、それに至る育種戦略を立案して 実行することになる。

エゾアワビの生物学的特徵を概略すると、本種は雌 雄異体であり、東北地方太平洋沿岸では 9 月〜 10 月 にかけて海水中に放卵、放精を行い、体外受精によっ て繁殖する。卵の大きさは約 $300 \mu \mathrm{m}$ 、産卵数は個体 変異を含めて正確に数えられていないようであるが、 数百万個は確実である。受精卵は水温 $20{ }^{\circ} \mathrm{C}$ で約 4 日 間幼生として浮遊した後、着底して稚具となる。稚 貝ははじめ付着珪藻を慨とするが、成長に従ってコ ンブなどの大型藻類を餌とするようになる。従って、 エゾアワビは沿岸域の海藻が繁茂している浅瀬に生 息している。一部の個体は 2 年 (若小貝)で最初の産 卵をするが、大部分は 4 年から 5 年で款長 $6 \sim 8 \mathrm{~cm}$ 程度の成貝になり、生涯に数度の繁殖を行う。自然 に扔ける寿命は不明だが、十数年は生存できると考 えられている。

エゾアワビは飼育と繁殖技術が確立されたとはい え、他の水産動物と同様に飼育の歴史は浅く、変異形 質の記録や蓄積がなく、家系の繁殖記録もない。従っ て、特定の変異形質を持った系統や養殖品種などは全 く確立されていない。また、変異形質の遺伝支配を解 明した例も極めて少ない。一方、エゾアワビの生物学 的特徽として陸上動物と際だって異なるところは、繁 殖様式が放卵放精による体外受精であり、多産なこと である。この特徵は、一腹仔の数が膨大であることか ら、同じ親個体の配偶子を用いて一世代で多数の交配 区を同時に作成できることを意味する。従って、一腹 仔で形質や遺伝変異の効率的分離が可能であり、多く の組み合わせを同時に作成して親の能力を一世代で判 定できる利点がある。また、受精後の発生の観察が容 易であるばかりではなく、卵や精子に対する人為的 操作も容易となり、染色体操作による遺伝分析や形 質の固定などに応用できる利点もある。反面、一家 族が多量の「きょうだい」を産することから、近親交

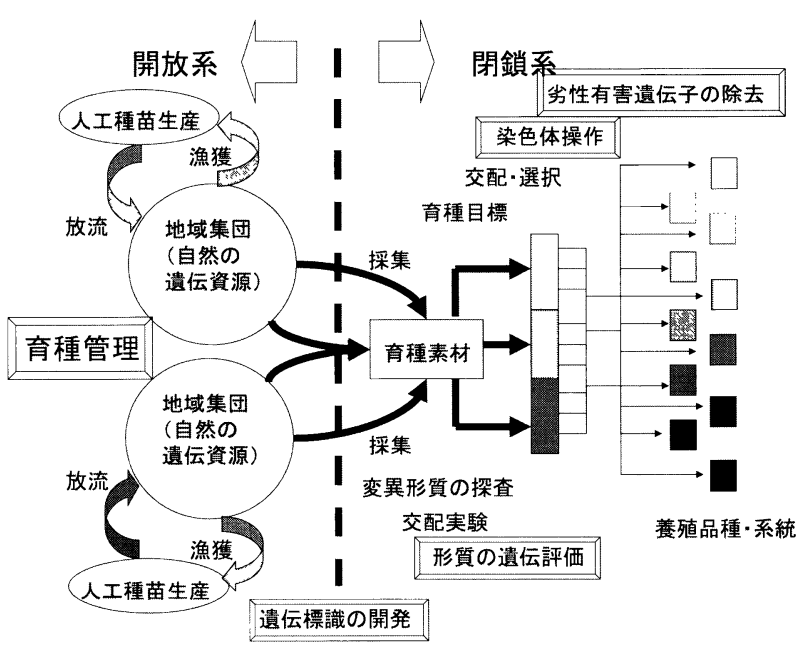

図 2. エゾアワビの育種戦略の概念

配が生じやすく、家系管理や個体管理がしにくい欠 点もある。

このような特徴を持つエゾアワビの育種を効率的に 行うには、集団の遺伝的組成を把握することや形質変 異に対するマーカーアシスト育種を行うために遺伝標 識を開発することが基盤として重要である。その上で、 開放系と閉鎖系における育種戦略を構築する必要があ る。すなわち、沿岸生態系 (開放系)に人工種苗を放流 し、遺伝資源の維持保全を行う育種管理に関しては、 (1) 自然集団の遺伝的変異性、繁殖構造、地理的遺伝 的分化のなど集団構造の解明、（2）人工種苗集団と天 然集団の遺伝的組成の比較、(3) 人工種苗集団が天然 集団に与える遺伝的影響の定量的定性的評価、(4) 遺 伝的組成の追跡調查と沿岸遺伝資源の保全生産方法の 策定、を行う必要がある。一方、陸上養殖施設 (閉鎖 系)における養殖品種の開発やそれに適した飼育方法の 開発には、（1）育種目標となる変異形質の探査、(2) 交 配実験による变異形質の遺伝支配の解明、(3) 遺伝支配 に適した選択と固定方法の考案、(4) 確立した系統・品 種の維持管理方法の策定が必要になる(図 2)。

以上のように、アワビ類は、陸上動物でいうと人間 が飼育を始めた段階にあると考えられる。この段階に おいて、現在どのような研究成果が蓄積されつつある かを次に述べる。

\section{3. 育種戦略に対する研究の現状と今後の課題}

3-1. 遺伝資源の存在様式に関する研究

日本に扔けるアワビ類の類縁関倸や種内の集団構造 を遺伝的に明らかにすることは、それらの生産と遺伝 
資源の保全を行う上で重要不可欠な課題である。日本 に生息するアワビ類に対して猪野 (1952) は形態的に類 似している大型アワビ類について解剖学的および発生 学的研究を行い、クロアワビ、マダカアワビ、メガイ を別種に、エゾアワビをクロアワビの亜種とした。し かし、クロアワビとエゾアワビは貝殼など外部形態の 個体変異が大きく、個体レベルでの識別は難しいため、 両者は主に分布域で分けられている。事実、小林ら （1992）は北海道から九州までの 10 地点から採集した 天然アワビ (エゾアワビとクロアワビが含まれる)の外 部形態を調べ、個体レベルでの識別が困難なことを報 告している。

このような問題に対して、アイソザイム遺伝子を標 識として日本産アワビ類 4 種 1 亜種 (メガイ、マダカ アワビ、クロアワビ、エゾアワビ、トコブシ)の類縁 関係を遺伝的に解析した報告がある（藤尾ら 1989； 原・藤尾 1992a）。どちらの結果においてもトコブシは 他の 3 種 1 亜種とは大きく異なるが、その他は極めて 近縁な関係であるとしている。その中でもクロアワビ
とエゾアワビでは共通対立遺伝子を保有しない分岐遺 伝子座が認められず、亜種よりも地方品種レベルの遺 伝的差異であると報告している。

エゾアワビとクロアワビを含め日本各地で採集した 標本についてアイソザイム分析で遺伝的差異を調べた 報告がある（藤尾ら 1989；原と藤尾 1992b；木島ら 1992)。木島 (1999) はそれらを総合し、北海道から九 州に至る、太平洋側 9 地域、日本海側 6 地域の合計 15 地域における集団構造を考察した。その報告では、各 地域間には遺伝子頻度に有意な差があることから、地 域毎にある程度独立した繁殖集団が形成されているこ とが示唆された。しかし、それらのうちLap 抢よび $P g m-2$ 遺伝子座に打ける遺伝子頻度には太平洋側抢よ び日本海側ともに南北方向への有意な地理的勾配が認 められること、さらには各地域間の地理的距離と $\mathrm{Nei}$ の遺伝的距離の間には有意な正の相関があることをみ いだし、近隣地域間での遺伝的交流が日本全域で連続 的に生じていることが示された (図 3)。実際、エゾア ワビは前述の通り秋季に各地沿岸岩礁域の浅瀬におい
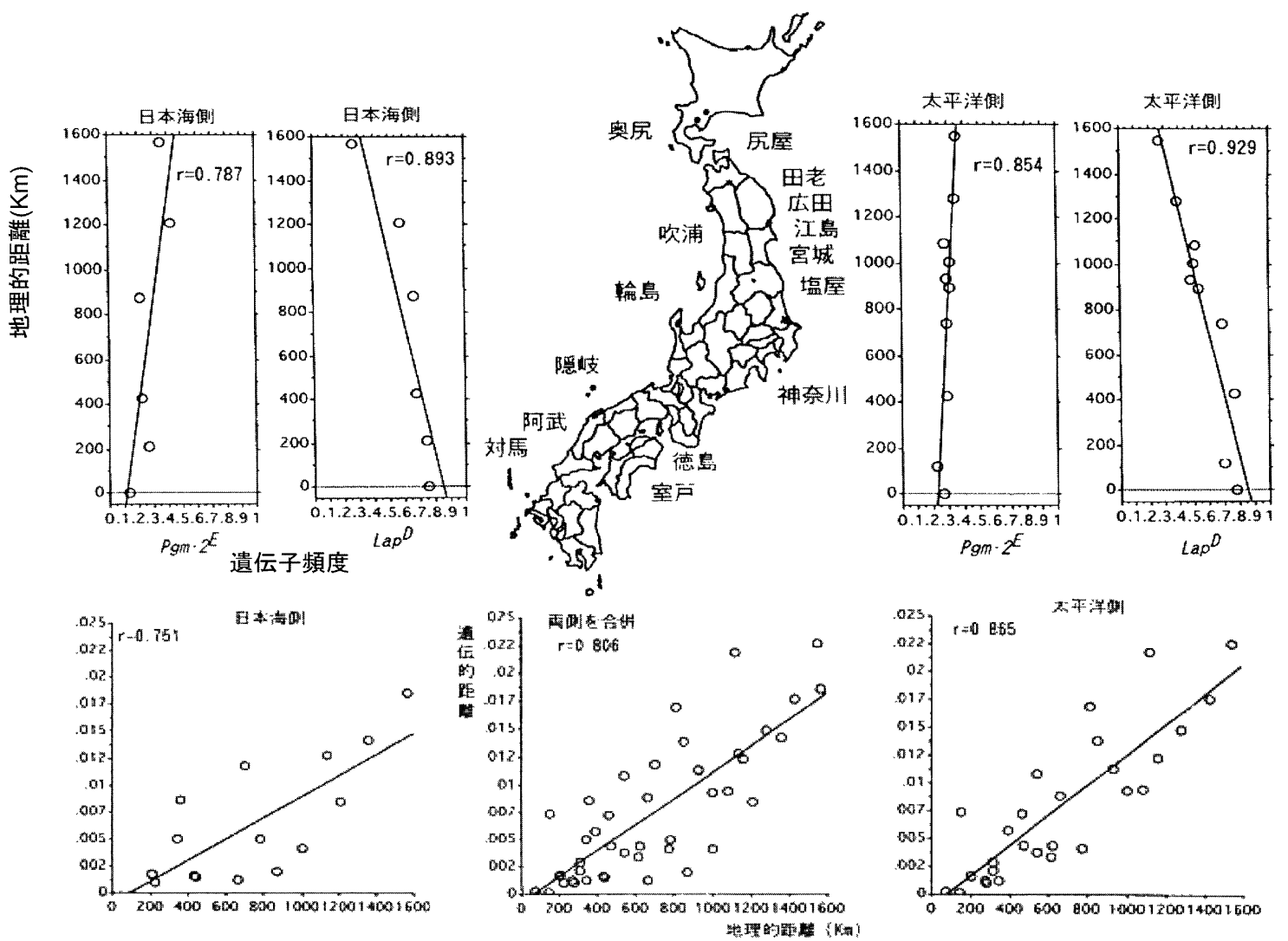

図 3. アイソザイムマーカーによるクロアワビとエゾアワビの地理的構造 
て莫大な数の放卵放精を行い、受精卵が約 4 日間の浮 遊生活を送るので、浮遊期には相当の搪散、近隣域で の混合が生じることは充分に考えられる。従って、エ ゾアワビとクロアワビは連続的混合が生じている同一 種内の地方品種と考え、それらは統合的な保全対象と して捉えるべきであると考えている。

\section{3-2 エゾアワビの人工種苗の遺伝的組成に関する研究} エゾアワビの自然集団に対する人工種苗放流の影響 を知るためにアイソザイム遺伝子を標識として人工種 苗集団の遺伝学的解析をした報告がある(木島ら 1992；古殿ら 1995 ；木島ら 1995）。それらによれば、 人工種苗集団は天然集団に比べて、へテロ接合体率の 平均は変わらないものの、各生産地あるいは生産ロッ 卜によってその值の変動が大きく、遺伝子頻度も有意 に大きく変動することが示された。また、1遺伝子座 あたりの対立遺伝子数には減少傾向がみられた。これ らの要因は人工種苗を作成するときに使われた親の数 が少ないために生産地あるいは生産ロットで遺伝的浮 動が生じたことによると考えられる。エゾアワビの天 然遺伝資源の保全と人工種苗生産放流を共存させるに は、天然集団の遺伝的組成を変化させないことが原則 になる。従って、各生産ロットの遺伝的変異性を低下 させないように親貝の数をできるだけ多く確保し、総 当たり交配 (多くの個体からの卵と精子を同時に混合 させるような交配でも良い)によって各個体の遺伝子 を分散させて保有するようにすることが重要である。 また、おなじ親貝を複数年使用せず、常に天然から採 集した個体を親貝とすること、さらに生産した人工種 苗の遺伝的組成は勿論のこと、天然遺伝資源の変化の 有無をみるために毎年天然集団の遺伝的組成を追跡調 査することが必要である。この点に関して、より変異 性が高い高感度マーカーを用いて人工種苗生産にかか わった親の数や組成、あるいは放流された人工種苗の 天然海域での再生産への寄与に関する研究がなされる ようになってきた。特にマイクロサテライトマーカー (MS 座) はH. kamtschatkana (Miller ら 2001)、H. rubra (Huang と Hanna 1998; Huang ら 2000; Evans ら 2000) 、H. rufescens (Kirby Б 1998)、H. asinina (Selvamani ら 2000)、H. discus discus (クロアワビ： Sekino と Hara 2001)、H. discus hannai (エゾアワビ：Li ら 2002; Li ら 2003a; Park ら 2003a; Sekino ら 2005) で開発されている。また、Liら (2003b) は複数の MS 座を用いることで人工種苗の個体の両親を特定できる ことを実際に示した。さらに、Liら（2004）は人工種
苗集団ではアイソザイム遺伝子で示されたと同様に、 天然集団に比べて遺伝的変異の顕著な減少が認められ ることを明らかにした。Sekinoら (2005) および砂田ら （2005）はMS 座を標識に天然海域における人工種苗放 流の効果を追跡する研究を始めている。

\section{3-3 遺伝变異の探査と遺伝支配に関する研究}

エゾアワビでは特定の形質を保有する家系や系統、 品種が確立されていないため、育種目標となる形質の 変異の探査から行っていかなくてはならない。アワビ 類の育種目標には高成長やプロポーションなどの形 態、そして可食部分の多さ (生肉重量) などが挙げられ る。これらの形質について調べる前に、その基本とな る形態の計測方法やその値の成長段階における変化な どの特徵を知らなくてはならない。

\section{(1)エゾアワビの形態形質の特徵}

小林ら (1991) は北海道、青森県、岩手県、宮城県の 天然エゾアワビを対象として、殸長、殸幅、殼高、全 重量、生肉重量、殼重量の計測値と、その值をもとに 殸長比、殼幅比、殼高比、全密度、生肉密度、殼密度、 身入りの計算值を求めている。その結果、殸幅と殼高 は殸長と高い正の一次相関があり、全重量、生肉重量、 殸重量と殼長との間には高い正の指数相関が認めら れ、それらの形質が殼の成長と共にある一定の割合で 増加することを示した。また、エゾアワビの形を表す 殼長比、殼幅比、殼高比は殼長に対して一定の值を取 り、款の形は稚貝になってから大きく変化しないこと、 さらに全密度、生肉密度、殸密度、身入りは殼長とは 関倸なく、変動が大きい形質であることを示した。こ の報告は天然に扔けるエゾアワビの量的形質の一般的 特徵を示すものであり、経済形質に対する改良・改善 の一つの基準となった。

\section{(2) 成長}

原(1992)はアワビ類の選択育種に関する総説の中で、 成長に関する交雑育種および選択育種の可能性につい てそれまでの結果をまとめて述べている。それによれ ば、エゾアワビ、クロアワビ、マダカアワビ、メガイ の形態分類上 3 種 1 亜種の種間雑種を作成したとこ ろ、どの組み合わせも $90 \%$ 以上の受精率が得られた こと、その中でエゾアワビとメガイの組み合わせでは それぞれの同種内の組み合わせよりも雑種第一代で成 長が良く、へテロシス効果があったとしている。種間 雑種では他に小池ら (1988) がマダカアワビとメガイの 組み合わせでへテロシスが認められると報告してい る。これらはアワビ類の育種において雑種強勢が利用 
できる可能性を示している。しかし 3 種 1 亜種すべて の組み合わせで交雑実験を行った報告はなく、今後、 交雑実験の事例を蓄積すると共に、同じ親を用いて種 間の総当たり交雑を行うなど体系的交雑実験が望まれ る。現在日本では体系的交雑実験の準備は整っていな いが、韓国では国立水産科学院が貝類育種研究セン夕 一を済州島に設置し、上記のすべての種について親の 確保と継代飼育が行われている。

一方、種内に㧍ける地域間交雑に関して、原 (1992) は青森県と岩手県の天然貝を用いた交雑 4 組を作成し て成長を追跡したが、異なる地域間の交雑が同じ地域 内の交配よりも必ずしも良い成長を示すことはなかっ たとしている。地域間交雑に関しても種間交雑と同様 に、各地域間の体系的交雑実験例を蓄積する必要があ るが、その中に暖流系であるクロアワビと寒流系であ るエゾアワビを含めた交雑実験計画を立案、実施する 必要がある。例えば、図3でいうと北海道 (奥尻：工 ゾアワビ)、岩手県 (広田：エゾアワビ)、德島県 (德 島：クロアワビ)、島根県 (隠岐：クロアワビ)の 4 地点 間における総当たり交配を行うと、亜種間交雑、種内 地域間交雑 (2 種それぞれについて) が同一親個体を用 いて同時に作成でき、体系的情報を効率的に得ること ができるだろう。

次に同種同地域内の交配において、原 (1989) は人工 種苗生産現場において親貝が異なる人工種苗の 3 ロッ ト（A、B、C）について、それぞれのロットを殸長で 大中小の 3 グループに分け、グループ毎に3ロットを 混合飼育 (個体識別をして同じ水槽で飼育すること) し た。その結果、どのグループもロット $\mathrm{B}$ が最も大きく、 ロットC、ロットAの順になっていたことから、成長 には遺伝要因が大きくかかわっていると考えた。次に 雌雄一対交配を行い、交配組の間での成長比較を行っ たところ、平均殼長の小さい交配区は成長のバラッキ が大きく、また成長が悪い個体の出現率が高くなって いた(原 1990)。このことは雌雄一対交配で得られた 子どもの中にも成長に関連した変異が存在することを 示唆している。さらに Hara と Kikuchi (1992) は岩手県 気仙町で発見された高成長を示す 1 群をとりだし、そ れらの選択実験を行ったところ、極めて良好な日間成 長量を示すことを確認し、成長に関する選択効果が期 待できることを示した。これに続いて、河原ら (1997) は高成長を示す個体を選択した岩手県 (気仙)の継代選 択 3 世代目、青森県の継代選択 2 世代目、そして北海 道、岩手県 (広田)、宮城県の選択 1 世代目、および選 択が行われていない岩手県 (広田)の天然集団から作成
した人工種苗を対象に、 4 年間に亘る分離飼育および 混合飼育実験を行って成長を比較した。その結果、ど ちらの飼育実験でも継代選択の青森県と岩手県 (気仙) で高い成長を示し、ついで継代選択 1 世代目の 3 ロッ トが続き、非選択が最も小さかった。また、この順位 は稚貝期から認められ、成貝でも変わらなかった。従 って、エゾアワビの成長の変異には遺伝的要因かかわ っていると考えられ、稚貝期に扔ける選択が有効であ ることが示唆された。

また、河原ら（1999）はエゾアワビの成長に関する 遺伝的要因の程度を明らかにするために、天然貝を 用いて 10 組の雌雄一対交配を行い、約 $10 \mathrm{~mm}$ の稚貝 となった時点 (受精後 188 日目) から 70 日目まで、 71 日目〜 140 日目、141日目〜 198 日目の 3 期間におけ る日間成長量に対して広義の遺伝率を求めた。その 結果、遺伝率はそれぞれ、0.50、0.62、0.22 となり、 岩手県沿岸で取られるエゾアワビでは選択効果が充 分期待できること示した。また、選択の効果が最も 顕著になるのは、受精後 8 ケ月から 9 ケ月であること が示唆された。

以上のことからエゾアワビの成長形質は遺伝的変異 を保有していることは確実であると考えられる。従っ て、今後は繁殖記録を確実に残して複数の高成長系統 および低成長系統を作成すると共に、マイクロサテラ イトDNAなどの高感度マーカーとの連鎖を捉えるこ とによってマーカーアシスト育種につなげていくこと が重要である。実際、Sekino ら (2005) はすでにエゾア ワビで38MS 座を開発し、それらの連鎖地図を作成す ると共に、成長と関係する MS 座の解析を始めている。

\section{(3) 形態形質}

アワビ類では、トコブシは殼の孔の数が $7 〜 8$ 個で あり大型のアワビ類の比べて多いことや、メガイは殼 の背が平坦で比較的丸い形状を示し、マダカアワビは メガイと同様に殸の形状が丸みを帯びているが平坦で はなく顕著に高くなり、款の孔が高い管状を呈するこ と、それに対してクロアワビはやや楕円形の形状を持 ち、殸の背がなめらかなアーチを描くがエゾアワビは 凹凸が顕著となるなど、種や亜種による特徵は認めら れている。しかし、これらの遺伝支配や遺伝要因に関 する研究はみられない。

一方、エゾアワビには款色変異が知られている(図 4、 巻末のカラーページ参照)。そのほとんどは飭料を起 源とする環境要因によるものである。しかし Kobayashi ら (2004) は継代している緑色の殸 (greenish) を持つエゾアワビの中に同じ飭料を与えているにもか 


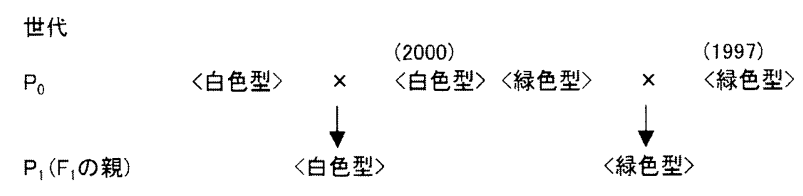

交配実験 I (2002)における緑色型と白色型の出現頻度

\begin{tabular}{|c|c|c|c|c|c|c|}
\hline \multirow{6}{*}{$F_{1}$} & 우 oा $^{-1}$ & $\begin{array}{c}\text { G18 } \\
\text { 〈緑色型〉 }\end{array}$ & $\begin{array}{c}\text { G41 } \\
\text { 〈緑色型〉 }\end{array}$ & $\begin{array}{c}\text { G56 } \\
\text { 〈緑色型〉 } \\
\end{array}$ & $\begin{array}{c}\text { W6 } \\
\text { 〈白色型〉 }\end{array}$ & $\begin{array}{c}\text { W7 } \\
\langle\text { 白色型 } \\
\end{array}$ \\
\hline & G9〈緑色型〉 & $G: W=1: 0$ & $G: W=1: 0$ & $G: W=1: 0$ & $G: W=1: 0$ & $G: W=1: 0$ \\
\hline & G58〈緑色型〉 & $G: W=1: 0$ & $G: W=1: 0$ & $G: W=1: 0$ & $G: W=1: 0$ & $\mathrm{G}: \mathrm{W}=1: 0$ \\
\hline & W1〈白色型〉 & $G: W=1: 0$ & $G: W=1: 0$ & $G: W=1: 0$ & $G: W=0: 1$ & $G: W=0: 1$ \\
\hline & W2 〈白色型〉 & $G: W=1: 0$ & $G: W=1: 0$ & $G: W=1: 0$ & $G: W=0: 1$ & $\mathrm{G}: W=0: 1$ \\
\hline & W3 〈白色型〉 & $G: W=1: 0^{-}$ & $G: W=1: 0$ & $\mathrm{G}: \mathrm{W}=1: 0$ & $G: W=0: 1$ & $G: W=0: 1$ \\
\hline & 交配実験 II (2 & 003) & $\downarrow$ & 1 & $\downarrow$ & \\
\hline \multirow{5}{*}{$F_{2}$} & 욕 & $\begin{array}{c}\text { W7 } \\
\text { 〈白色型〉 }\end{array}$ & $\begin{array}{c}11-6 \\
\text { 〈緑色型〉 }\end{array}$ & $\begin{array}{c}17-3 \\
\text { 〈緑色型〉 }\end{array}$ & $\begin{array}{c}17-4 \\
\text { 〈緑色型〉 }\end{array}$ & \\
\hline & W1〈白色型〉 & $G: W=0: 1$ & $G: W=1: 1$ & & $\mathrm{G}: \mathrm{W}=1: 1$ & \\
\hline & W3 〈白色型〉 & $\mathrm{G}: \mathrm{W}=0: 1$ & & & $G: W=1: 1$ & \\
\hline & 10-1〈緑色型〉 & & & & $G: W=3: 1$ & \\
\hline & 10-4〈緑色型〉 & & & $\mathrm{G}: \mathrm{W}=3: 1$ & & \\
\hline
\end{tabular}

図 5. エゾアワビの款色における白色型と緑色型の交配 実験様式と両型の分離比

かわらず青紫色 (bluish) の殸を持つ個体が約 $30 \%$ 出現 している家族を発見し、その家族を用いて緑色型同士、 緑色型と青紫色型、青紫色型と緑色型、そして青紫色 型同士の交配実験を行った。その結果、緑色型同士の 3 組のこどもはすべて緑色型、青紫色型同士の 6 組で はすべて青紫色型、緑色型と青紫色型の交配では 2 組 とも緑色型と青紫色型が $1: 1$ で分離し、青紫色型と 緑色型の交配では 4 組すべてが緑色型となったことか ら、この款色変異は 1 遺伝子座における優性の緑色と なる対立遺伝子 $(G)$ と青紫色となる劣性の対立遺伝子 （b）によると考えた。これを確証するために、青紫色 型が出現した家族と雄親を同じくする別の家族を用い て緑色型同士の交配実験を行った。その結果、13交配 区のうち 2 交配区で緑色型と青紫色型が $3: 1$ の比で 分離し、この款色変異の遺伝支配が確実となった。

さらに小林ら (2005) は人工種苗生産場で白色がかっ た殸を持つ個体 (白色型)を取り出し、白色型同士の交 配ですべてが白色となった交配区の個体を用い、雌と して緑色型 2 個体と白色型 3 個体、雄として緑色型 3 個体と白色型 2 個体の総当たり交配を行った（図 5)。 その結果、白色型同士の子どもはすべて白色型となっ たが、その他の交配はすべて緑色型となった。そこで、 緑色と白色の正逆の交配区において出現した緑色型を 用いて白色型との戻し交配を行った。その結果、緑色 型と白色型がどの組み合わせとも $1 ： 1$ に分離したこ
とから、白色型は 1 遺伝子座において白色となる劣性 対立遺伝子によって、生じることが判明した。しかし この白色型が色素形成不全変異であるのか、白色の色 素を形成しているのかは未解決である。また、緑色型 と対立関係にある白色型の劣性対立遺伝子と、同じく 緑色型と対立関係にある青紫色型の劣性対立遺伝子の 関係は今後の問題として残されている。

以上のような殸色変異は今直ちに経済形質と結びっ けて考えることはできないが、特別な品種が作成でき たときにはこの遺伝子を入れて付加価值を付けること にも応用できるだろう。また、エゾアワビの稚貝はネ クタイピンなどのアクセサリーとして利用されたり、 ラデン細工の材料としても利用されていることから、 殸色変異は育種素材としては貴重な研究につながるも のと期待される。

\section{3-4. 形質の効率的分離及び固定に関する研究 (染色 体操作)}

体外受精であり多産である魚類では、卵や精子が扱 いやすいため、受精から発生にかけての染色体操作が 行われ、人為雌性発生二倍体や人為雄性発生二倍体、 卵操作クローン、三倍体や四倍体の作成、あるいは人 為性転換技術と組み合わせて全雌生産などの性の統御 が行われている(鈴木編著 1989)。エゾアワビも体外 受精であり多産であることから染色体操作による形質 の分離、有害遺伝子の除去、作成系統の固定などを行 っていくことが期待される。

貝類の正常な受精と初期発生を図 6 に示した。魚類 で行われている染色体操作とはゲノムセットを人為的 に組み合わせることを基本とする。魚類とエゾアワビ を含む貝類との顕著な違いは、魚類が受精直前では第 一成熟分裂が終了し第二成熟分裂中期で精子の受け入 れを待つのに対し、貝類は第一成熟分裂初期で精子を 受け入れるところである。また、魚類では 1 個の精子 が卵門から侵入するが貝類では特定の侵入場所がな く、極めて多数の精子が卯表面にあるジェリ一層のあ りとあらゆる所に突き刺さり、先体反応によって最も 早く卵膜を通過できたものが受精する。いずれにして も染色体操作を行うためには、紫外線照射や $\gamma$ 線照射 による雄性核あるいは雌性核の遺伝的不活性化（受精 能力あるいは卵割の刺激能力はあるが、核として融合 しないこと) 技術 (ゲノムの削除技術) と高温処理や高 圧処理、あるいは化学薬品処理などによるゲノムの倍 加技術が必要となる。その詳細は成書 (鈴木編著 1989) に譲り、ここではエゾアワビについて実際に行われた 


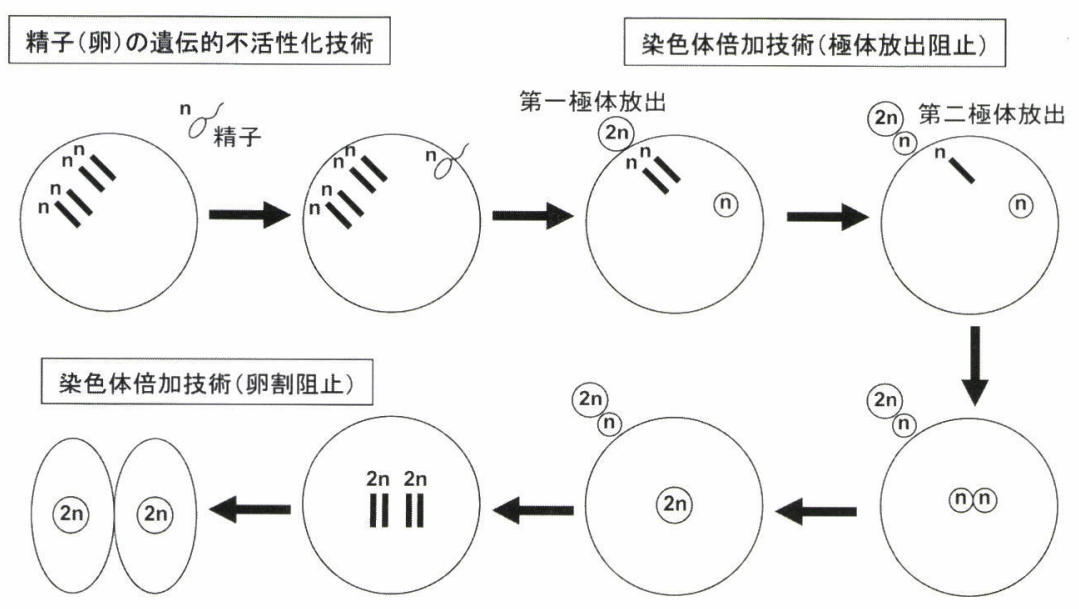

図 6. エゾアワビにおける染色体操作の概念図


図 7. 紫外線照射によるエゾアワビ精子の損傷 $\mathrm{a}$ : 正常精子 (無照射)、 $\mathrm{b}$ : 鞭毛離脱、 $\mathrm{c}$ : 先体破壊、 $\mathrm{d}$ ：鞭毛離脱と先体破壊

例を挙げて概説する。

Arai ら（1984、1986）はアワビ類の染色体操作を世界 に先駆けエゾアワビで行った。彼らは精子の遺伝的不 活性化および第二極体放出阻止の条件を検討し、人為 此性発生二倍体と三倍体の作出を行った結果、人為三 倍体の作出は高率で成功したが、雌性発生二倍体は極 めて低率であった。その後アワビ類の三倍体や四倍体 の作成に関する報告がなされたが (Fujino ら 1987；奥 村ら 1996; Yang ら 1997; Yang ら 1998; Zhan ら 1998；Okumura ら 1998；Mao ら 2000）、雌性発生二倍 体に関する報告は認められない。これは、染色体倍加
技術はある程度確立できたが、雌性核および雄性核の 遺伝的不活性化技術が確立されていないためである。 Kijima (1992) はエゾアワビの精子核の遺伝的不活性化 が困難な原因はUV 照射によって精子核ばかりではな く先体も破壊されるためではないかと予想した。これ について Liら (1999a) はUV照射のエゾアワビ精子に 及ぼす影響を定量的に示すと共に精子の先体の破壊と 鞭毛の離脱の証拠を電子顕微鏡写真で示した（図 7)。 Li ら (2000a、2000b) はこの現象が他の具類 (マガキ、 ホタテガイ)でも同様に認められることを報告してい る。またUV照射精子で受精した場合の雄性核の動態 
を細胞学的観察によって明らかにし、雌性発生二倍体 作出技術の難点を浮き彫りにした $(\mathrm{Li} ら 2000 \mathrm{c})$ 。しか し、Liら (1999b) はごく一部であるがエゾアワビにお いて受精能力を持つ遺伝的不活性化精子の存在を認 め、雌性発生二倍体の作成に成功している。さらに Li ら (2004) はエゾアワビではないが、マガキの卵のUV 照射による雌性核の遺伝的不活性化を行ったが、その 成功率は精子核の場合よりも低率であった。

以上のことから染色体操作による育種には遺伝的不 活性化技術の進展が必要である。また染色体操作技術 とは別に、遺伝子導入技術や細胞操作技術の開発が始 められている。ただし特定形質を保有する系統や品種 がほとんどない現在では、それらの先端技術と平行し て遺伝変異の探查、系統の作成を行うことが如何に重 要であるかを感じている。

\section{3-5 遺伝資源および系統·品種の維持に関する研究 （近交弱勢亡有害遺伝子）}

閉鎖系において特定形質を保有する個体を選択して 系統を作成するにしても、開放系においてある程度限 定された数の親による人工種苗生産を行い、遺伝資源 を保全するにしても近交弱勢現象は最も気を付けるべ き、回避すべき現象である。それにもかかわらず、魚 類においても貝類においても近交弱勢現象の機構や要 因に関する研究は極めて少ない。その理由として、近
交弱勢研究には少なくとも実際に近親交配を行わなく てはならず、それには雌雄一対交配による家族を複数 作成し、飼育して親にしなくてはならないことが挙げ られる。エゾアワビのように成熟まで $4 \sim 5$ 年間かか る動物では近交一世代目のデー夕を取るまでに少なく とも数年必要とし、近交数世代に亘る研究を実施する には二十数年の年月を要する。しかし、一方ではエゾ アワビは多産であることから一組の交配実験の子ども から形質の分離比が捉えられることや、同じ親を用い て複数の交配が同時に行える利点を持っている。

この特性を生かして、Parkら (2005a) は図8 に示し たように 1994 年に 10 組の雌雄一対交配を行い、10 家 族を作成した。それらのうち 1999 年には家族 A から 雌 4 個体、雄 2 個体、家族 B から雌 2 個体、雄 1 個体 を取り出し、総当たり交配を行うことで兄妹交配 1 代 目を 10 組、その対照となる非近親交配 6 組を作成し、 受精率を調べた。その後、それらを2つに分け岩手県 水産技術センターと東北大学大学院農学研究科複合生 態フィールド教育研究センター・複合水域生産システ ム部(女川の海生センター)の異なる飼育環境で飼育し、 ベリジャー幼生の奇形率、約 4 ケ月後と約 1 年後の成 長 (殻長) と生残率を計測した。さらに2000 年には家 族 D から雌 3 個体、雄 3 個体、家族 $\mathrm{G}$ から雌 1 個体、 雄 2 個体、2001 年には家族 G から雌 1 個体、雄 2 個体、 家族 $\mathrm{I}$ から雌 1 個体、家族 $\mathrm{J}$ から雌 1 個体、雄 1 個体



図 8. エゾアワビにおける近親と非近親交配を含めた交配実験システム 
表 1. 近親及び非近親交配を含むエゾアワビの総当たり交配における奇形率

\begin{tabular}{|c|c|c|c|}
\cline { 2 - 4 } \multicolumn{1}{c|}{1999 年 } & \multicolumn{3}{|c|}{ 雄 } \\
\hline 渋 & $\mathrm{A} 11$ & $\mathrm{~A} 15$ & $\mathrm{~B} 14$ \\
\hline $\mathrm{A} 16$ & 6.1 & 3.5 & \\
\hline $\mathrm{A} 19$ & 3.8 & 6.9 & 1.3 \\
\hline $\mathrm{A} 21$ & 5.5 & 11.9 & \\
\hline $\mathrm{A} 23$ & 6.5 & 1.9 & 4.4 \\
\hline $\mathrm{B} 17$ & 4.0 & 0.8 & 8.6 \\
\hline $\mathrm{B} 40$ & 0.0 & 0.0 & 6.4 \\
\hline
\end{tabular}

\begin{tabular}{|c|c|c|c|cc|}
\cline { 2 - 6 } \multicolumn{1}{c|}{2000 年 } & \multicolumn{5}{|c|}{ 雄 } \\
\hline 雌 & D13 & D28 & D39 & G1 & G8 \\
\hline D5 & 5.1 & 7.6 & 4.1 & 2.0 & 5.7 \\
\hline D9 & 7.3 & 7.2 & 5.2 & 5.6 & 5.7 \\
\hline D25 & 6.0 & 4.7 & 3.1 & 2.5 & 1.0 \\
\hline G23 & 1.9 & 0.0 & 1.2 & 2.2 & 2.9 \\
\hline
\end{tabular}

\begin{tabular}{|l|r|r|r|}
\cline { 2 - 4 } \multicolumn{1}{c|}{2001 年 } & \multicolumn{2}{|c|}{ 雄 } & \\
\hline \hline 雌 & G15 & G17 & $\mathrm{J18}$ \\
\hline $\mathrm{G} 10$ & 10.6 & 4.7 & 5.8 \\
\hline $\mathrm{I23}$ & 1.6 & 1.2 & 6.2 \\
\hline $\mathrm{J} 42$ & 5.8 & 1.2 & 3.7 \\
\hline
\end{tabular}

表 2. 兄妹交配と非兄妹交配による奇形率の比較

\begin{tabular}{|c|c|c|c|c|}
\hline 交配年 & \multicolumn{3}{|c|}{ 兄妹交配 } & 非兄妹交配 \\
\hline \multirow[t]{2}{*}{1999} & $\mathrm{~A}(8)$ & B (2) & $\mathrm{A}+\mathrm{B}(10)$ & $\mathrm{A} \times \mathrm{B}(6)$ \\
\hline & $5.7 \pm 3.0$ & $7.5 \pm 1.5$ & $6.1 \pm 2.8$ & $1.7 \pm 1.9$ \\
\hline \multirow[t]{2}{*}{2000} & $\mathrm{D}(9)$ & $\mathrm{G}(2)$ & $D+G(11)$ & $\mathrm{D} \times \mathrm{G}(9)$ \\
\hline & $5.6 \pm 1.6$ & $2.5 \pm 0.5$ & $5.0 \pm 1.9$ & $2.8 \pm 2.2$ \\
\hline \multirow[t]{2}{*}{2001} & $\mathrm{G}(2)$ & $\mathrm{J}(1)$ & $\mathrm{G}+\mathrm{J}(3)$ & $\mathrm{G} \times \mathrm{I}(2), \mathrm{G} \times \mathrm{J}(2), \mathrm{I} \times \mathrm{J}(1)$ \\
\hline & $7.6 \pm 4.2$ & 3.7 & $6.3 \pm 3.7$ & $3.2 \pm 2.3$ \\
\hline 全平均 & & & $5.6 \pm 2.5$ & $2.6 \pm 2.1$ \\
\hline
\end{tabular}

を取り出し、それぞれ総当たり交配を行い、受精率と 奇形率を計測した。その結果、受精率および成長 (款 長)では兄妹交配区と非兄妹交配区の間に有意な差は 認められなかったが、ベリジャー幼生の奇形率では兄 妹交配区で顕著に高い交配区がみられ（表 1)、全体と しても兄妹交配区は非兄妹交配区より有意に奇形率が 高くなった (表2)。また生残率は岩手県及び東北大学 のどちらで飼育しても、約 4 ケ月後拉よび約 1 年後共 に有意ではないが兄妹交配区で低くなる傾向を示し た。これらのことからエゾアワビにおいて近交弱勢現 象が兄妹一世代でも奇形率や生残率において顕在化す ることが示された。

さらにPark ら (2003b) は1999 年の交配区を対象に、 MS 座をマーカーとして兄妹交配区と非兄妹交配区の 遺伝子型の分離を調べた。その結果、多くの交配区で はすべて矛盾なくアリル型の分離を示したにもかかわ らず、兄妹交配区においてヌルアリルのホモ接合体が 全く見つからなかったことから、家族 Aにおいてこの ヌルアリルと連鎖した劣性致死遺伝子が示唆された。 ただこの場合のマーカーアリルが PCR 増幅の認めら れないヌルアリルであることから、確証を得るには至
っていない。しかし、このような独創的な交配実験を 大規模に行うことができれば、エゾアワビの近交弱勢 現象や劣性有害遺伝子の存在を定性的、定量的に解析 できるものと期待される。現在、岩手県水産技術セン ターと東北大学海生センターとの共同研究で近交弱勢 現象に関するより多くの事例を追跡中である。

\section{おわりに}

ここまでエゾアワビの育種の現状について述べてき た。アワビ類は他の水産生物から比べると親貝の養成 技術、人工種苗生産技術が確立され、一歩先に進んで いるかに思われるが、陸上動物と比べれば育種は始ま ったばかりと考えて良いだろう。それを陸上動物と同 じように数千年かけて育種するのでは人口爆発が進む 地球に拀ける食料生産には間に合わない。従って、こ れまで蓄積されてきた先達である家畜や作物の育種技 術を学ぶと共にアワビ類の生物学的特性を充分生かし た育種方法を考案して行かなくてはならない。

東アジアに扔けるアワビ類の増養殖生産の現状をみ ると、日本は天然遺伝資源がまだ豊富であり、その保 全と生産を両立させるべく人工種苗生産と放流を行っ 
ている。一方、中国はすでに天然資源は枯渇している ようであり、ほとんどすべてが会社 (公司)に属する沿 岸の施設において完全養殖が行われている。韓国はそ の中間的状況にあり、国の研究機関で養殖生産を目指 している。そのような状況の中でこれからのアワビ類 の育種を考えると、まず、開放系での育種管理は、ま だ天然遺伝資源がある程度確保されている日本と韓国 において 3-1 および 3-2で述べた方向で重点的に行う 必要がある。一方、閉鎖系での育種では、3-3 2 -4 で述べた研究を深化させ、日本、韓国、中国の各地に おいて作成される人工種苗から高成長や高生残、ある いは色彩変異や形態変異を抽出し、それぞれの国で育 種素材として確保すると共に、交配と飼育の記録の明 確な継代飼育によって系統を作成していく必要がある だろう。それらを作成していく段階において有害遺伝 子の除去を行わなくてはならないが、そのために 3-5 で述べたような大規模な交配実験を陸上養殖施設と飼 育管理体制が整備されている中国において推進するこ とが期待される。加えて、生物側の遺伝的改善と同時 に低環境負荷、省エネルギー、効率的生産につながる 飼育施設の改善も行う必要があると考える。このよう にして各国で作出され、保有されている育種素材を相 互に交換させながら特徴のある系統を作成維持してい くアワビの育種が進められることを期待している。も はや日本一国でアワビの生産と遺伝資源の保全を担う 時代は過去となった。アワビを珍重する東アジア全体 で遺伝育種を行うことが望まれる。元々アワビには国 境がないのであるから。

\section{引用文献}

Arai K, Naito F, Fujino K. 1986. Triploidization of the Pacific Haliotis discus hannai with temperature and pressure treatments. Bulletin of Japanese Society of Scientific Fisheries, 52: 417-422.

Arai K, Naito F, Sasaki H, Fujino K. 1984. Gynogenesis with UV ray irradiated sperm in the Pacific abalone Haliotis discus hannai. Bulletin of Japanese Society of Scientific Fisheries, 50: 2019-2024.

Evans B, White RWG, Elliott NG. 2000. Characterization of microsatellite loci in the Australian blacklip abalone (Haliotis rubra, Leach). Molecular Ecology, 9(8): $1183-1184$.

Fujino K, Okumura S, Inayoshi H. 1987. Temperature tolerance differences among normal diploid and triploid Pacific abalone. Bulletin of Japanese Society of
Scientific Fisheries, 53: 15-22.

藤尾芳久・尾庭きよ子・湯沢麻美・高橋寛爾. 1989 .

アワビ類の遺伝的変異と集団構造. 海洋生物集団

の識別に関する先導的評価手法の開発事業報告

書，459-476. 日本水産資源保護協会. 東京.

古殿太郎・木島明博 - 藤尾芳久. 1995. エゾアワビ天

然集団と人工種苗の量的形質と質的形質における

遺伝的差異. 水産育種, 22: 31-37.

原素之. 1992. アワビの育種一アワビにおける選抜・

交雑育種一。水産育種, 18: 1-12.

原素之. 1989. エゾアワビ人工種苗の親貝による成長

の差異. 水産育種, 14: 39-42.

原素之. 1990. エゾアワビ人工種苗の成長におよぼす

遺伝的要因. 東北区水産研究所研究報告, 52: $73-77$.

原素之・藤尾芳久. 1992a. エゾアワビ 4 種の遺伝的 類縁関係. 水産育種, 17: 55-61.

原素之・藤尾芳久. 1992b. 天然アワビにおけるアイ

ソザイム遺伝子の地理的分布. 東北区水産研究所 研究報告, 54: 115-124.

Hara M, Kikuchi S. 1992. Increasing the growth rate of abalone Haliotis discus hannai, using selective techniques. NOAA Technical Report, NMFS, 106: $21-26$.

Huang B, Hanna PJ. 1998. Identification of three polymorphic microsatellite loci in blacklip abalone, Haliotis rubra (Leach), and detection in other abalone species. Journal of Shellfish Research, 17(3): $795-799$.

Huang BX, Peakall R, Hanna PJ. 2000. Analysis of genetic structure of blacklip abalone (Haliotis rubra) populations using RAPD, minisatellite and microsatellite markers. Marine Biology, 136(2): $207-216$.

猪野峻. 1952. 邦产アワビ属の増殖に関する生物学的 研究. 東海区水産研究所研究報告, 5: 1-102.

河原郁恵 - 野吕忠勝 - 大森正明 - 木島明博. 1999. 工 ゾアワビ稚貝期の成長に関する遺伝率の推定. 水 产育種, 28: 95-103.

河原郁恵 - 野吕忠勝 - 大森正明 - 支倉理 - 木島明博. 1997. 種苗生産施設で選抜されたエゾアワビの成 長に対する選択効果. 水産育種, 25: 81-90.

Kijima A. 1992. Effect of UV irradiation on genetic inactivation of sperm using marketing tissue culture petri-dish in the Pacific abalone Haliotis discus hannai. 
Tohoku Journal of Agricultural Research, 42(3-4): $73-81$.

木島明博. 1994. 水産育種の課題. 動物遺伝研究会 誌, 22(2): 55-64.

木島明博. 1999. 第 6 章 アワビの遺伝的分化と集団構 造. 藤尾芳久 編著「水族における遺伝資源の存在 様式と保全」, 78-88. (財) 力キ研究所. 仙台. 木島明博 - 古殿太郎 - 藤尾芳久. 1995. エゾアワビ天 然集団における身入りの変異性と遺伝的変異性。 水産育種, 22: 39-44.

木島明博・池田実・藤尾芳久. 1992.アイソザイムか らみたエゾアワビ人工種苗の遺伝的特徴. 水産育 種, 18: 53-63.

Kijima, A., C. Park, Q. Li and T. Kobayashi. 2003. Inbreeding depression traits in the Pacific abalone (Haliotis discus hannai) by factorial mating experiments. 5th International Abalone Symposium, Abstract p.166. Qingdao, China.

Kirby VL, Villa R, Powers DA. 1998. Identification of microsatellites in the California red abalone, Haliotis rufescens. Journal of Shellfish Research. 17(3): $801-804$.

Kobayashi T, Kawahara I, Hasekura O, Kijima A. 2004. Genetic control of blueish shell color variation in the Pacific abalone, Haliotis discus hannai. Journal of Shellfish Research, 23(4): 1153-1156.

小林俊将 - 原素之 . 菊地省吾 - 坂本晋 - 木島明博. 2005. エゾアワビに出現した白色型の款色の遺伝 支配について。水産育種，35: 印刷中.

小林正裕・木島明博・藤尾芳久. 1991. エゾアワビの 量的形質の把握とその特徵。水産育種, 16 : $33-41$.

小林正裕・木島明博・藤尾芳久. 1992. 日本沿岸にお けるアワビの量的形質の地理的勾配. 水産育種, 17: $39-48$.

小池康之・孫振興・隆島史夫１988．アワビ交雑種稚 貝の摂飭と成長について。水産増殖，36(3): $231-235$

Li Q, Hisatsune T, Kijima A. 2004. Effects of Ultraviolet Irradiation on Inactivation of Egg Chromosomes and Nuclear Behavior During Early Development of Pacific Oyster. Marine Biotechnology, 6: 291-297.

Li Q, Osada M, Kashihara M, Hirohashi K, Kijima A. 1999a. Effect of ultraviolet irradiation on genetical inactivation and morphological structure of sperm of the Pacific abalone Haliotis discuss hannai. Tohoku Journal of Agricultural Research, 50(1,2): 1-10.

Li Q, Osada M, Kashihara M, Hirohashi K, Kijima A. 1999b. Artificially induced gynogenetic diploid in the Pacific abalone Haliotis discuss hannai. Fish Genetics and Breeding Science, 28: 85-94.

Li Q, Osada M, Kashihara M, Hirohashi K, Kijima A. 2000a. Effect of ultraviolet irradiation on genetical inactivation and morphological features of sperm of the Pacific oyster Crassostrea gigas. Fisheries Science, 66(1): $91-96$

Li Q, Osada M, Kashihara M, Hirohashi K, Kijima A. 2000b. Effect of ultraviolet irradiation on genetical inactivation and morphological structure of sperm of the Japanese scallop, Patinopecten yesoensis. Aquaculture, 186: 233-242.

Li Q, Osada M, Kashihara M, Hirohashi K, Kijima A. 2000c. Cytological studies on artificially induced gynogenesis in the Pacific abalone. Fisheries Science, 66: $701-707$.

Li Q, Park C, Kijima A. 2002. Isolation and characterization of microsatellite loci in the Pacific abalone, Haliotis discus hannai. Journal of Shellfish Research, 21(2): $811-815$

Li Q, Park C, Kijima A. 2003b. Allelic transmission of microsatellites and application of kinship analysis in newly hatched Pacific abalone larvae. Fisheries Science, 69: 883-889.

Li Q, Park C, Kobayashi T, Kijima A. 2003a. Inheritance of microsatellite DNA markers in the Pacific abalone Haliotis discus hannai. Marine Biotechnology, 5: $331-338$.

Li Q, Park C, Kobayashi T, Kijima A. 2004. Loss of genetic variation in hatchery strains of the Pacific abalone (Haliotis discus hannai) at microsatellite loci. Aquaculture, 235: 207-222.

Mao LJ, Wang ZC, Liu XQ, Li YJ, Gao YM. 2000. Induction of polyploid in the Pacific abalone by caffeine-heat shock treatments. Acta Genetica Sinica, 27: $959-965$.

Miller KM, Laberee K, Kaukinen KH, Li S, Withler RE. 2001. Development of microsatellite loci in pinto abalone (Haliotis kamtschatkana). Molecular Ecology Notes, 1: 315-317.

Okumura S, Furukawa S, Sasaki T, Shimaoka M, Horikawa 
C, Yamamori K. 1998. Suppression of both 1st and 2nd meiotic divisions by caffeine treatment for the production of tetraploid Pacific abalone, Haliotis discus hannai (Archaeogastropoda : Haliotidae). Chromosome Science, 2: 123-127.

奥村誠一・古川末広・寺田栄作・山口史敬・山森邦

夫. 1996. 第 1 及び第 2 成熟分裂阻害により誘起 されたエゾアワビの雌性発生 4 倍体幼生. 水産育 種, 23: 21-27.

Park C, Li Q, Kobayashi T, Kijima A. 2003. Characterization of novel microsatellite DNA markers in the Pacific abalone, Haliotis discus hannai. Fish Genetics and Breeding Science, 32(1): 1-6.

Park C, Li Q, Kobayashi T, Park K, Kijima A. 2003. Detection of null alleles and recessive lethal gene linked with the microsatellite locus in the Pacific abalone, Haliotis discus hannai, by factorial mating experiments. $5^{\text {th }}$ International Abalone Symposium, Abstract p.168. Qingdao, China.

Sekino M, Hara M. 2001. Microsatellite DNA loci in Pacific abalone Haliotis discus discus (Mollusca, Gastropoda, Haliotidae). Molecular Ecology Notes, 1: $8-10$.

Sekino M, Saido T, Fujita T, Kobayashi T, Takami H. 2005. Microsatellite DNA markers of Ezo abalone (Haliotis discus hannai): a preliminary assessment of natural populations sampled from heavily stocked areas. Aquaculture, 243: 33-47.

Selvamani MJP, Degnan SM, Paetkau D, Degnan BM.
2000. Highly polymorphic microsatellite loci in the Heron Reef population of the tropical abalone Haliotis asinina. Molecular Ecology, 9(8): 1184-1186.

砂田桃代 - 菅野愛美 - 小林俊将 - 遠藤敬 - 井ノ口伸 幸・木島明博. 2005. マイクロサテライトDNA を用いたエゾアワビ人工種苗の親子判定および放 流効果推定への応用. 水産育種，36: 投稿中.

鈴木亮. 1989. 水産増養殖と染色体操作. 日本水産学 会監修 水産学シリーズ 75, 1-122. 恒星社厚生 閣. 東京.

浮永久 · 大森正明 - 河原郁恵 - 石田亨一 - 柳澤豊重. 1995. アワビ類の種苗生産技術. 栽培漁業技術シリ ーズ No.2，1-175. (社) 日本栽培漁業協会．東京。

Yang HS, Ting YY, Chen HC. 1997. Effect of cold shock on the production of triploid zygotes and the embryonic development of small abalone, Haliotis diversicolor supertexta Lischke. Acta Zoological. Taiwanica, 8: $67-78$.

Yang HS, Ting YY, Chen HC. 1998. Blocking polar body with cytochalasin $\mathrm{B}$ in the fertilized eggs of the small abalone, Haliotis diversicolor supertexta (Lischke), and the development and ploidy of the resultant embryos. Aquaculture Research, 29: 775-783.

Zhang G, Yang Z, Chang Y, Song J, Ding J, Wang Y, Wang R. 1998. Triploid induction in Pacific abalone Haliotis discus hannai Ino by 6-dimethylaminopurine and the performance of triploid juveniles. Journal of Shellfish Reserarch, 17: 783-788. 